\title{
Acute Appendicitis in Pregnancy, Management and Outcomes: A Hospital Based Study
}

\author{
Irfan Nazir Mir ${ }^{1}$, Atif Naeem Raja ${ }^{1}$, ${ }^{*}$ Mir Mujtaba Ahmad ${ }^{2}$ and Raja Nadeem ${ }^{2}$ \\ ${ }^{1}$ Department of General Surgery, GMC, India \\ ${ }^{2}$ Department of General Surgery, HIMSR, India
}

Submission: December 16, 2016; Published: January 06, 2017

*Corresponding author: Mir Mujtaba Ahmad, Senior Resident, Department of Surgery, HIMSR, New Delhi, India, Email: drmirmujtaba1@gmail.com

\begin{abstract}
Background: Acute appendicitis is the most common surgical emergency in pregnancy. The purpose of this study was to investigate the clinical presentation, management and outcomes (both maternal and fetal) in pregnant patients admitted with features of acte appendicitis.

Material and Methods: A total of 56 pregnant women with features of acute appendicitis were admitted, out of these 51 patients underwentappendectomy, and 5 patients were managed conservatively in our hospital, between January 2010 and June 2016, weretrospectively analyzed the results in terms of presentation, management and fetomaternal outcomes in these patients.

Results: Intraoperative findings and patrhological reports were supportive of the diagnosis of acute appendicitis in 88.23\% (45/51) of the cases who were operated. There was perforated appendicitis in 11.7\% (6/51). Abdominal pain, nausea, vomiting, leukocyte count, CRP and body temperature were had a low yield in establishing the correct diagnosis.USG abdomen was found to be cheap, safe and effective diagnostic tool with correct diagnosis in about $95 \%$. There was no maternal mortality related to the appendectomy. One patient (1.78\%) developed fecal fistula following appendectomy. Pregnancy complications were found to be considerable: $3 / 8$ (37.5\%) who underwent appendectomy for appendicitis during the first trimester aborted spontaneously. Second trimester appendectomy for appendicitis was followed by premature delivery and fetal demise in 7/36 (19.44\%) third trimester appendectomy for appendicitis was followed by premature delivery in $1 / 7(14 \%)$. We found increase in pregnancy complications in cases with perforated appendicitis, (5/6), $83.3 \%$ of these patients suffered fetal loss during follow up period.
\end{abstract}

Conclusion: Appendicitis in pregnancy should be suspected when a pregnant woman complains of new abdominal pain. No laboratory finding was found to be diagnostic for acute appendicitis during pregnancy. Considerable fetal loss was found after appendectomy during pregnancy in the first and second trimester. Increased complications in cases with perforated appendicitis were observed. The combination of symptoms, ultrasonography and clinical judgment is vital in deciding which patient needs surgical treatment.

Keywords: Acute appendicitis; Pregnancy; Pregnancy outcomes

\section{Introduction}

Although a rarity, acute appendicitis remains the most common non obstetric emergency in pregnancy, the incidence is approximately 1 in 1500 pregnancies. The incidence in the first trimester range from $19 \%$ to $36 \%$ [1-4]. The incidence is higher in the second trimester, ranging from $27 \%$ to $60 \%$ [1-3] but it has been noted that the incidence decreases from $15 \%$ to $33 \%$ in the third trimester; [1-4] the rates of Perforation pregnant patients have been reported as high as $55 \%$ of cases, compared with $4 \%$ to $19 \%$ of the general population [2].

\section{Differential diagnosis}

The following are possible differential diagnoses of pain in right lower abdomen in pregnant females (Table 1).
Table 1: Differential diagnoses of pain in right lower abdomen in pregnant females.

\begin{tabular}{|c|c|}
\hline $\begin{array}{c}\text { Non-Obstetrical \& } \\
\text { Gynaecological }\end{array}$ & Obstetrical and Gynaeological \\
\hline Urinary tract infection & Ectopic pregnancy \\
\hline Acute cholecystitis & Miscarriage (early gestation) \\
\hline Gastroenteritis & Twisted or ruptured ovarian cyst \\
\hline Right ureteric colic & Pelvic inflammatory disease \\
\hline Right pyelonephritis & $\begin{array}{c}\text { Preterm labour (advanced } \\
\text { gestation) }\end{array}$ \\
\hline Perforated peptic ulcer & Placental abruption \\
\hline Mesenteric adenitis & Degenerating uterine leiomyoma \\
\hline
\end{tabular}




\section{Investigation}

Leucocytosismay not be helpful and reliable in pregnant women as leukocytosis (WBC count as high as $16000 / \mu \mathrm{L}$ ) is normal physiological alterations during pregnancy. Furthermore, not all pregnant women with appendicitis have leukocytosis [5] C-reactive protein (CRP) can also be used but is unreliable $[6,7]$. Diagnostic imaging may be considered in doubtful cases. Ultrasonography remains single most reliable and easily available investigation with a high specificity (75-100\%) [8]. It is relatively cheap, fast and noninvasive [9]. Another imaging tool that is useful to diagnose appendicitis is the magnetic resonance, but it is costly and not easily available in emergency setup [8]. Perforation of the appendix causes escape of its contents into the abdominal cavity. This can lead to peritonitis, miscarriage, preterm labor and fetal or maternal death $[10,11]$. According to various studies, perforated appendix increases the rate of preterm contraction and preterm labor [11]. Acute appendicitis has been reported to be associated with a fetal loss risk of $1.5 \%$ to $9 \%$, however the risk increases up to $35 \%$ after perforation [10].

\section{Material and Methods (Figure 1)}

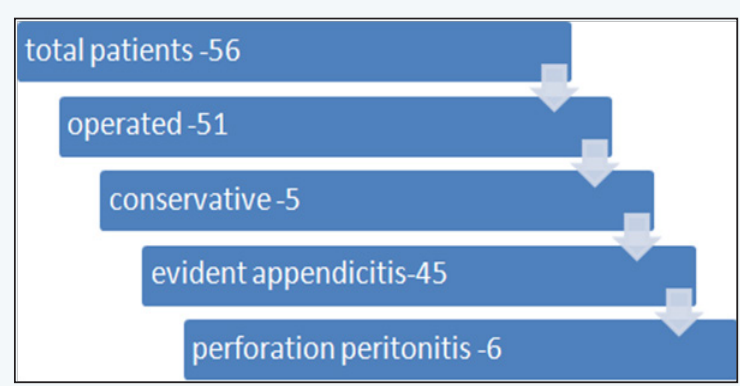

Figure 1: Chart showing acute appendicitis during pregnancy.

Table 2: Table showing number of patients and ages in years.

\begin{tabular}{|c|c|}
\hline Age in years & Number of patients \\
\hline $24 \_26$ & 16 \\
\hline $27 \_29$ & 28 \\
\hline $30 \_32$ & 12 \\
\hline Average age 27.7 & Total 56 \\
\hline
\end{tabular}

Fifty six patients, with features of acute appendicitis during pregnancy managed between January 2010 to June 2016 in government medical college hospital are presented. Age group varied from 24 years to 32 years with median age of 27.73 years. Ten patients presented during first trimester, thirty nine during second trimester and seven during third trimester. Fifty one patients underwent emergency appendectomy on strong clinical, biochemical and USG evidence of appendicitis. In 51 patients, appendectomy was performed through a muscle splitting, classical grid iron incision or incision over the point of maximum tenderness in advanced gestation. General anaesthesia was administered in all patients. All patients received postoperative parenteral antibiotics for three days. All patients were operated by open surgery due to unavailability of laparoscope in emergency. Five patients were managed conservatively, two out of these five patients had appendicular lump, and the other three had delayed presentation and regression of signs and symptoms. (Tables $2 \& 3$ ) (Figure 2).

Table 3: Table showing period of gestation and number of patients.

\begin{tabular}{|c|c|}
\hline Period of gestation & Number of patients \\
\hline Ist trimester & 10 \\
\hline Second trimester & 39 \\
\hline Third trimester & 7 \\
\hline
\end{tabular}

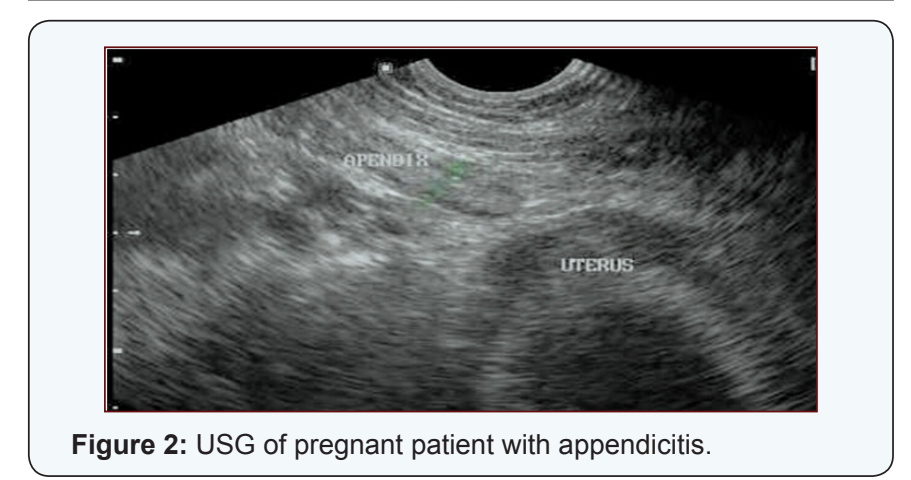

\section{Results}

Table 4: Presenting symptoms in pregnant patients.

\begin{tabular}{|c|c|c|c|}
\hline SYMPTOMS & $\begin{array}{c}\text { I }^{\text {ST }} \text { TRIMESTER } \\
\text { TOTAL 10 }\end{array}$ & $\begin{array}{c}\text { 2 }^{\text {NDTRIMESTER }} \\
\text { TOTAL 39 }\end{array}$ & $\begin{array}{c}3^{\text {RD }} \text { TRIMESTER } \\
\text { TOTAL 7 }\end{array}$ \\
\hline PAIN RIF & $10(100 \%)$ & $12(30.7 \%)$ & $1(14.3 \%)$ \\
\hline PAIN RUQ & - & $24(61.5 \%)$ & $4(57.1 \%)$ \\
\hline Diffuse PAIN & - & $3(7.7 \%)$ & $2(28.5 \%)$ \\
\hline Nausea & $8(80 \%)$ & $11(28.2 \%)$ & $3(42.8)$ \\
\hline Vomiting & $7(70 \%)$ & $13(33.3 \%)$ & $1(14.2 \%)$ \\
\hline Anorexia & $8(80 \%)$ & $15(38.4 \%)$ & $2(28.5 \%)$ \\
\hline Fever & $6(60 \%)$ & $5(12.8 \%)$ & $1(14.2 \%)$ \\
\hline Bleeding PV & - & $1(2.5 \%)$ & - \\
\hline
\end{tabular}

Table 5: Physical signs in pregnant patients.

\begin{tabular}{|c|c|c|c|}
\hline SIGNS & $\begin{array}{c}1^{\text {st }} \text { trimester } \\
\text { Total 10 }\end{array}$ & $\begin{array}{c}\mathbf{2}^{\text {nd }} \text { trimester } \\
\text { Total 39 }\end{array}$ & $\begin{array}{c}3^{\text {rd }} \text { trimester } \\
\text { Total 7 }\end{array}$ \\
\hline Tachycardia & $8(80 \%)$ & $19(48.7 \%)$ & $5(71.4 \%)$ \\
\hline Tender RIF & $10(100 \%)$ & $11(28.2 \%)$ & - \\
\hline Tender RUQ & - & $23(59 \%)$ & $4(57.1 \%)$ \\
\hline $\begin{array}{c}\text { Diffuse } \\
\text { tenderness }\end{array}$ & - & $5(12.8 \%)$ & $3(42.8 \%)$ \\
\hline $\begin{array}{c}\text { Rebound } \\
\text { tenderness }\end{array}$ & $6(60 \%)$ & $29(74.3 \%)$ & $5(71.4 \%)$ \\
\hline
\end{tabular}




\section{Open Access Journal of Surgery}

\begin{tabular}{|c|c|c|c|}
\hline Guarding & $7(70 \%)$ & $21(54 \%)$ & $3(42.8 \%)$ \\
\hline $\begin{array}{c}\text { Appendicular } \\
\text { lump }\end{array}$ & - & $2(51.2 \%)$ & - \\
\hline $\begin{array}{c}\text { Decreased } \\
\text { bowel sounds }\end{array}$ & $5(50 \%)$ & $22(56.4 \%)$ & $6(85.7 \%)$ \\
\hline
\end{tabular}

Fiftysix pregnant females with diagnosis of acute appendicitis were admitted in our hospital. The average age was 27.7 years (Table 2). 10 patients were in first trimester, 39 in second trimester and 7 patients in third trimester of pregnancy (Table 3). Fifty one appendectomies were performed among these patients, five patients were managed conservatively. Among those managed conservatively, 2 patients were in first trimester and 3 in second trimester. There were 18 primis and rest multigravidas. The presenting symptoms and signs of acute appendicitis are enumerated in (Tables 4 \& 5). All patients presented with a history of abdominal pain. Twenty four patients complained of nausea and twenty one complained vomiting while 25 had anorexia and distaste for food during the previous 24 hours. Twelve patients were febrile on examination and 33 had polymorphonuclear leucocytosis on laboratory analysis. C reactive protein was raised in $85.7 \%$ patients, USG abdomen revealed acute appendicitis in 42 patients, two patients presented with appendicular lump, confirmed on ultrasound examination. Intraoperative and histology confirmed appendicitis in 45 patients (88.23\%), six patients (11.7\%) had perforated appendicitis, there was no evidence of acute appendicitis in $11.7 \%(6 / 51)$ (Table 6).

Table 6: Laboratory findings in pregnant patients with appendicitis.

\begin{tabular}{|c|c|c|c|}
\hline Lab findings & $\begin{array}{c}\mathbf{I}^{\text {st }} \text { trimester } \\
\text { Total 10 }\end{array}$ & $\begin{array}{c}\mathbf{2}^{\text {nd }} \text { trimester } \\
\text { Total 39 }\end{array}$ & $\begin{array}{c}3^{\text {rd }} \text { trimester } \\
\text { Total 7 }\end{array}$ \\
\hline $\begin{array}{c}\text { Leucocytosis } \\
10,000-16000\end{array}$ & $6(60 \%)$ & $21(54 \%)$ & $2(28.5 \%)$ \\
\hline Counts >16000 & $2(20 \%)$ & $12(30.7 \%)$ & $3(42.8 \%)$ \\
\hline $\begin{array}{c}\text { Polymorphs } \\
>80 \%\end{array}$ & $6(60 \%)$ & $22(56.4 \%)$ & $5(71.4 \%)$ \\
\hline Elevated CRP & $9(90 \%)$ & $33(84.6 \%)$ & $6(85.7 \%)$ \\
\hline Bacteriuria & $3(30 \%)$ & $12(30.7 \%)$ & $1(14.2 \%)$ \\
\hline Pyuria & $4(40 \%)$ & $12(30.7 \%)$ & $2(28.5 \%)$ \\
\hline USG evidence & $7(70 \%)$ & $32(82 \%)$ & $3(42.8 \%)$ \\
\hline
\end{tabular}

The average period of hospitalization was 5.2 days (range 4-8 days). The postoperative complications in the patients are summarized in (Table 7). Pregnancy complications were found to be considerable: $3 / 8$ (37.5\%) who underwent appendectomy for appendicitis during the first trimester aborted spontaneously. Second trimester appendectomy for appendicitis was followed by abortion or premature delivery in 7/36 (19.44\%). Third trimester appendectomy for appendicitis was followed by premature delivery in $1 / 7$ (14\%) (Table 8$), 2$ out of 5 patients managed conservatively had spontaneous abortions during follow up period. There was no maternal mortality reported in our study. We found increase in pregnancy complications in cases with perforated appendicitis, (5/6), 83.3\% of these patients suffered fetal loss during follow up period.

Table 7: Complications in operated cases of pregnant patients with appendicitis.

\begin{tabular}{|c|c|c|c|c|}
\hline Complication & $\begin{array}{c}\mathbf{I}^{\text {st }} \\
\text { trimester } \\
\text { Total 8 }\end{array}$ & $\begin{array}{c}\mathbf{2}^{\text {nd }} \\
\text { trimester } \\
\text { Total 36 }\end{array}$ & $\begin{array}{c}3^{\text {rd }} \\
\text { trimester } \\
\text { Total 7 }\end{array}$ & Total \\
\hline Fever & 2 & 10 & 2 & $\begin{array}{c}14 / 51 \\
(27.4 \%)\end{array}$ \\
\hline $\begin{array}{c}\text { Wound } \\
\text { infection }\end{array}$ & 1 & 6 & 2 & $\begin{array}{c}9 / 51 \\
(17.6 \%)\end{array}$ \\
\hline Fecal fistula & - & 1 & - & $\begin{array}{c}1 / 51 \\
(1.8 \%)\end{array}$ \\
\hline
\end{tabular}

Table 8: Obstetric outcomes in operated cases of pregnant patients with appendicitis.

\begin{tabular}{|c|c|c|c|}
\hline $\begin{array}{c}\text { Obstetric } \\
\text { outcome }\end{array}$ & $\begin{array}{c}\mathbf{I}^{\text {st }} \text { trimester } \\
\text { Total 8 }\end{array}$ & $\begin{array}{c}\mathbf{2}^{\text {nd }} \text { trimester } \\
\text { Total 36 }\end{array}$ & $\begin{array}{c}\mathbf{3}^{\text {rd }} \text { trimester } \\
\text { Total 7 }\end{array}$ \\
\hline abortion & $37.5 \%(3 / 8)$ & $8.5 \%(3 / 36)$ & - \\
\hline $\begin{array}{c}\text { Premature } \\
\text { delivery }\end{array}$ & - & $11.2 \%(4 / 36)$ & $14 \%(1 / 7)$ \\
\hline
\end{tabular}

\section{Discussion}

The cases of pregnancy with appendicitis are challenging. the physiological changes occurring normally in pregnancy make it difficult to establish a diagnosis. The physical findings and laboratory values that are often used for diagnosis of appendicitis are altered in pregnancy and are confused with normal physiological alterations. The surgeon has limitations in the use of various diagnostic procedures during pregnancy because of adverse effects of these on the fetus possible teratogenicity like X-ray abdomen, CT scan. The surgeon is treating two patients simultaneously, and considerations of both are to be kept in mind [12]. Appendicitis occurs more frequently during the first two trimesters than the third, as was seen in this study. The symptoms of appendicitis can be confused with morning sickness and ectopic pregnancy during first trimester and twisted ovarian cyst in early second trimester [13].

During third trimester, patient complains of pain, higher and more lateral in the abdomen or right flank which is commonly confused with ureteric colic [13]. Guarding and rigidity are difficult to elicit in third trimester due to stretched abdominal muscles [14]. Laboratory examination of blood and urine may be of little diagnostic aid. Abortions in early pregnancy and preterm delivery remain high even with timely intervention. Fetal mortality is high due to septicaemia and prematurity. Appendectomy should be performed on suspicion of the 
presence of appendicitis just as if pregnancy was not present [15]. If surgery is performed before the appendix ruptures, complications can be minimized, as perforation worsens the obstetric outcomes. A multidisciplinary approach is needed to minimize adverse effects, involving simultaneous gyenecological consultation [16].

\section{Conclusion}

Fetal mortality has been reported between $2-8.5 \%$ but increases to more than $35 \%$ in perforation and peritonitis $[17,18]$. Preterm labour is a problem, therefore timely intervention is reasonable and advocated [19].

\section{References}

1. Hée P, Viktrup L (1999) The diagnosis of appendicitis during pregnancy and maternal and fetal outcome after appendectomy. Int J Gynaecol Obstet 65(2): 129-135.

2. Tracey M, Fletcher HS (2000) Appendicitis in pregnancy. Am Surg 66: 555-559.

3. Al-Mulhim AA (1996) Acute appendicitis in pregnancy. A review of 52 cases. Int Surg 81(3): 295-297.

4. Andersen B, Nielsen TF (1999) Appendicitis in pregnancy: diagnosis, management and complications. Acta Obstet Gynecol Scand 78(9): 758-762.

5. Pastore PA, Loomis DM, Sauret J (2006) Appendicitis in pregnancy. J Am Board Fam Med 19(6): 621-626.

6. Wijesuriya LI (2007) Imaging as an aid to the diagnosis of acute appendicitis. Malaysian Fam Physician 2(3): 106-109.
7. Guttman R, Goldman RD, Koren G (2004) Appendicitis during pregnancy. Can Fam Physician 50: 355-357.

8. Weiss CR, Macura KJ (2003) Diagnosis of ruptured appendicitis: Role of magnetic resonance imaging. J Wom Imag 5(4): 192-198.

9. Bezjian AA (1984) Pelvic masses in pregnancy. Clin Obstet Gynecol 27: 402-415.

10. Tamir IL, Bongard FS, Kelin SR (1990) Acute appendicitis in pregnant patient. Am J Surg 160(6): 571-661.

11. Mourad J, Elliott JP, Erickson L, Lisboa L (2000) Appendicitis in pregnancy: new information that contradicts long-held clinical beliefs. Am J Obstet Gynecol 182(5): 1027-1029.

12. Kort B, Katz VL, Watson WJ (1993) The effect of nonobstetric operation during pregnancy. Surg Obstet Gynecol 177(4): 371-376.

13. Sharp HT (1994) Gastrointestinal surgical conditions during pregnancy. Clin Obstet Gynaecol 37(2): 306-315.

14. Masters K, Levine BA, Gaskill HV, Sirinek KR (1984) Diagnosing appendicitis during pregnancy. Am J Surg 148(6): 768-771.

15. Al-Mulhim AA (1996) Acute appendicitis in pregnancy. Int Surg 81(3): 295-302.

16. Tamir IL, Bongard FS, Klein SR (1990) Acute appendicitis in a pregnant patient. Am J Surg 160(6): 571-576.

17. Doberneck RC (1985) Appendectomy during pregnancy. Am Surg 51(5): 265-273.

18. Weingold AB (1983) Appendicitis in pregnancy. Clin Obstet Gynecol 26(4): 801-810.

19. Mourad J, Elliot JP, Eridason L (2000) Appendicitis in pregnancy: new information that contradicts long held clinical beliefs. Am J Obstet Gynaecol 182(5): 1027-1029.

Your next submission with JuniperPublishers will reach you the below assets

- Quality Editorial service

- Swift Peer Review

- Reprints availability

- E-prints Service

- Manuscript Podcast for convenient understanding

- Global attainment for your research

- Manuscript accessibility in different formats ( Pdf, E-pub, Full Text, Audio)

- Unceasing customer service

Track the below URL for one-step submission https://juniperpublishers.com/online-submission.php 